Eur. J. Clin. Chem. Clin. Biochem.

Vol. 31, 1993, pp. 389-393

(C) 1993 Walter de Gruyter \& Co. Berlin - New York

\title{
Development and Evaluation of a Time-Resolved Immunofluorimetric Assay for Thyrotropin
}

By U. Mißler ${ }^{1}$, Ulrike Gaida ${ }^{2}$ and W. G. Wood ${ }^{3}$

1 Department of Neurosurgery, Medical University of Lübeck, Lübeck, Federal Republic of Germany

${ }^{2}$ Department of Internal Medicine, Medical University of Lübeck, Lübeck, Federal Republic of Germany

${ }^{3}$ Institute for Clinical Laboratory Diagnosis, Municipal Hospital of the Hanseatic City of Stralsund, Stralsund, Federal Republic of Germany

(Received December 9, 1992/March 11, 1993)

Summary: The assay described in this article is based on microtitre plate technology; it employs an europium label. The streptavidin-biotin system has been used and all components are commercially available.

The lower detection limit of the assay is below $0.003 \mathrm{mU} / 1$; the standards are made up in newborn calf serum. Correlation with a commercially available immunoluminometric assay (Berilux - Behringwerke) was excellent $(\mathrm{r}=0.92, \mathrm{n}=201$ data pairs, range covered $0-10 \mathrm{mU} / \mathrm{l})$. The regression line using a double logarithmic transformation was: $(\log y)=0.91(\log x)-0.08$.

The assay precision at the clinical limits of decision - i.e. between hyper- and euthyroidism $(0.2 \mathrm{mU} / \mathrm{l})$ and eu- and hypothyroidism ( $4 \mathrm{mU} / \mathrm{l})$ - was acceptable. The median coefficient of variation was $1.93 \%$ in the range $0.02-1 \mathrm{mU} / 1$ and $2.11 \%$ in the range $1.0-3.5 \mathrm{mU} / 1$, with both values being determined from precision profiles using 214 and 188 data pairs respectively. Inter-assay coefficients of variation determined in over 30 consecutive assays were under $6 \%$ in the range $1.3-20 \mathrm{mU} / \mathrm{l}$.

From 201 sera measured in both assays, 194 sera gave clinically identical values; 8 sera gave clinically discrepant values.

The assay has a large dynamic range covering a concentration range of above 5 decades, with the count ratio between the $100 \mathrm{mU} / 1$ standard and the zero standard being in excess of $4150: 1$. A high dose hook effect was first seen in excess of $500 \mathrm{mU} / 1$. The maximum signal was achieved around $150 \mathrm{mU} / \mathrm{l}$, which registered around $8 \times 10^{6}$ counts per second, a figure more than 8000 times higher than that in the zero standard.

\section{Introduction}

The introduction of immunometric methods for thyrotropin $(1,2)$ led to an indirect standardisation of assays for this analyte, as well as to a shortening of assay time and an improvement of the lower detection limit and analytical specificity.

The discrimination between eu- and hyperthyroid patients became possible with this "second generation" of assays for thyrotropin (3). Further developments in assay technique have led to non-radioisotopic immunometric assays that have a comparable, if not better, lower detection limit as compared with immunoradiometric assays $(4,5)$. Some authors now go as far as prizing "third generation" thyrotropin assays (6), although the lower detection limit of a method depends on the state of the art of analysis.

The lower detection of such assays is often more theoretical than practical, as the matrix of the zero standard has been manipulated to give a low background signal. More important, however, is the ability of an assay for thyrotropin to discriminate correctly between eu- and hyperthyroid patients in terms of 
defined reference ranges $(6,7)$, and it may very well be that the methods giving the lowest thyrotropin concentration are not necessarily those giving the best clinical discrimination $(6-8)$.

This brief communication describes the development and clinical evaluation of an immunometric assay for thyrotropin using a streptavidin-europium complex as label. The assay appears to show no serum matrix effects, which allows the standard curve to be set up in assay buffer. Using human thyrotropin as standard (calibrated against the WHO 2nd IRP 80/558), levels of $0.001 \mathrm{mU} / 1$ thyrotropin can be distinguished from the zero standard, while it can be set up using commercially available reagents.

\section{Materials and Methods}

\section{Materials : :}

Ninety-six-well microtitre plates (Maxisorp) were obtained from Nunc, Roskilde, Denmark.

Antibodies to thyrotropin were purchased from BoehringerMannheim, Mannheim, Germany. These consisted of a monoclonal antibody, which was immobilised onto the microtitre plate wells, and a polyclonal $F_{a b}$ fragment from sheep, which was biotinylated by the authors.

Standards for thyrotropin used for calibration purposes were obtained from the Behringwerke, Marburg a.d.L., Germany. Human thyrotropin for internal standards was purchased from Kabi (Kabi-Pharmacia, Erlangen, Germany).

Amidocaproylbiotin-N-hydroxysuccinimide was purchased from Sigma, Deisenhofen, Germany, the europium labelling reagent, from Pharmacia, Freiburg i. Br., Germany.

The Berilux TSH immunoluminometric assay (Behringwerke) was used for comparison.

The time-resolved fluorimeter (Arcus 1232) was from Wallac, Turku, Finland and the 250-sample semiautomated luminometer (Berthold LB-952 16T) from EG \& G Berthold, Wildbad, Germany.

Other chemicals and buffer substances were obtained from Sigma or Merck, Darmstadt, Germany.

All reagents were made up in the laboratory, including those for the time-resolved fluorescence measurement. The assay buffer and enhancement solution were made up as listed below:

\section{Assay buffer}

Tris $0.05 \mathrm{~mol} / \mathrm{l}, \mathrm{NaCl} 0.15 \mathrm{~mol} / \mathrm{l}$, bovine serum albumin $5 \mathrm{~g} / \mathrm{l}$ bovine gamma globulins $0.5 \mathrm{~g} / \mathrm{l}$, diethylene triaminopentaacetate (DTPA) $80 \mathrm{mg} / \mathrm{l}, \mathrm{NaN}_{3} 0.15 \mathrm{~mol} / \mathrm{l}$, Tween $200.1 \mathrm{ml} / \mathrm{l}$, adjusted to $\mathrm{pH} 7.75$.

\section{Wash solution}

Tris $0.05 \mathrm{~mol} / \mathrm{l}, \mathrm{NaCl} 0.15 \mathrm{~mol} / \mathrm{l}$, EDTA $0.01 \mathrm{~mol} / \mathrm{l}, \mathrm{NaN}_{3} 0.15$ $\mathrm{mol} / \mathrm{l}$, Tween $200.1 \mathrm{ml} / \mathrm{l}$, adjusted to $\mathrm{pH} 7.5$.

\section{Enhancement solution}

Acetic acid $0.01 \mathrm{~mol} / \mathrm{l}$, tris-n-octyl phosphine oxide $38 \mathrm{mg} / \mathrm{l}$, potassium phthalate $166 \mathrm{mg} / \mathrm{l}$, theonyltrifluoroacetone 222 $\mathrm{mg} / \mathrm{l}$, Triton X-100 $2 \mathrm{ml} / \mathrm{l}$.

\section{Methods}

The coating of the microtitre plates, the preparation of the standards and the assay procedure are shown in table 1.

$$
\text { i }
$$

Tab. 1a. Components and assay scheme for the thyrotropin time resolved immunofluorimetric assay (TRIFMA)

\section{- Coating of the microtitre plate}

Each well was coated with 500 ng monoclonal antibody MAK 8 in phosphate buffer, $\mathrm{pH} 8.7$, using a coating volume of $250 \mu \mathrm{l}$. The minimum coating time was $18 \mathrm{~h}$ at ambient temperature. Saturation of free binding sites was performed directly before assay using $50 \mathrm{mmol} / \mathrm{l}$ carbonate buffer containing $10 \mathrm{~g} / \mathrm{l}$ bovine serum albumin, $\mathrm{pH}$ 9.6, with a minimum saturation time of $45 \mathrm{~min}$ and a volume of $350 \mu \mathrm{l} /$ well.

\section{- Labelling of the liquid-phase antibody}

Sheep anti-human thyrotropin ( $F_{a b}$ fragment) was labelled with amidocaproyl biotin $\mathrm{N}$-hydroxysuccinimide ester at $\mathrm{pH}$ 9.4 for $18 \mathrm{~h}$ at ambient temperature. Separation of unreacted biotin was performed on a $15 \times 1 \mathrm{~cm}$ column of Ultrogel AcA-54 (IBF, Gif-sur-Yvette, F.) using $0.05 \mathrm{~mol} / 1$ Tris- $\mathrm{HCl}$, pH 7.5, as eluent.

\section{- Preparation of standards}

Human thyrotropin (Kabi-Pharmacia) was dissolved in a minimal amount of $0.15 \mathrm{~mol} / 1 \mathrm{NaCl}$ and further diluted with newborn calf serum to give a stock solution of around $3 \mathrm{U} / \mathrm{l}$. Standards were made by diluting portions of stock solution to give standards containing $100,10,1,0.1,0.01$ and $0.002 \mathrm{mU} / 1$ thyrotropin in newborn calf serum. These standards were portioned and stored at under $-30^{\circ} \mathrm{C}$ until use. Each portion was used for one assay, with any surplus material being discarded.

- Assay scheine

- $100 \mu$ l standard, sample or control

- $100 \mu \mathrm{l}$ biotinylated anti-thyrotropin

- incubate 120 min at ambient temperature on shaker

- wash with wash buffer ( 3 cycles on plate washer)

- $200 \mu \mathrm{l}$ streptavidin-europium

- incubate $30 \mathrm{~min}$ as above and wash (5 cycles on plate washer)

- $200 \mu$ l enhancement solution

- incubate as above and measure in ARCUS 1232 (1 s/ well)

The biotinylation of the antibodies was performed using the active ester method with an $\mathrm{N}$-hydroxysuccinimide ester, as has already been described in detail for both biotin (9) and luminogens (10).

The assay used for comparison (Berilux TSH) was set up according to the manufacturer's instructions. The clinically relevant ranges established in Lübeck for this kit were: hyperthyroid patients $<0.1 \mathrm{mU} / 1$, euthyroid patients $0.2-3.4 \mathrm{mU} / 1$ and hypothyroid patients $>5 \mathrm{mU} / \mathrm{l}$. These are not identical with those in the kit instructions. They have been established over a 36-month period in which the kit was used routinely on over 20000 samples.

\section{Results}

This assay demonstrates the wide measuring range obtainable through low background and high specific signal (dynamic signal range). Table 2 shows a compound standard curve to demonstrate this point. The 
Tab. 2. Standard curve and precision data for thyrotropin

Compound standard curve derived from 10 assays (mean values of duplicates)

\begin{tabular}{lrc}
\hline $\begin{array}{l}\text { Standard } \\
(\mathrm{mU} / \mathrm{l})\end{array}$ & $\begin{array}{l}\text { Counts } \\
\left(\mathrm{s}^{-1}\right)\end{array}$ & $\mathrm{B}_{\mathrm{s}} / \mathrm{B}_{\mathrm{o}}{ }^{*}$ \\
\hline 0 & 986 & 1.00 \\
0.001 & 1324 & 1.34 \\
0.01 & 2205 & 2.27 \\
0.1 & 5513 & 5.59 \\
1 & 38280 & 38.8 \\
10 & 401010 & 407 \\
100 & 4126250 & 4185 \\
\hline
\end{tabular}

* Ratio between the counts for standard in question and the zero standard.

Precision Data

\begin{tabular}{llll}
\hline Sample & $\begin{array}{l}\text { Mean } \\
\text { concentration } \\
\mathrm{mU} / \mathrm{l}\end{array}$ & $\begin{array}{l}\text { Coefficient } \\
\text { of variation } \\
(\mathrm{CV} \text { or } \mathrm{s} \%)\end{array}$ & $\begin{array}{l}\text { Number of } \\
\text { data used }\end{array}$ \\
\hline
\end{tabular}

Intra-assay data

$\begin{array}{lccc}\text { K1 } & 0.53 & 2.17 & 40 \\ \text { P2 } & 0.81 & 4.51 & 36 \\ \text { K2 } & 3.24 & 3.45 & 36 \\ \text { K3 } & 10.9 & 2.07 & 36\end{array}$

Inter-assay data

\begin{tabular}{lrll} 
K4 & 1.27 & 5.63 & 33 \\
K5 & 7.73 & 3.77 & 34 \\
K6 & 19.9 & 3.91 & 34 \\
\hline
\end{tabular}

maximal signal is reached at a concentration around $150 \mathrm{mU} / 1$ and reaches almost $8 \times 10^{6}$ counts per second. A high dose hook effect is first seen in excess of $500 \mathrm{mU} / \mathrm{l}$, i. e. at concentrations which do not occur physiologically.

Table 2 also shows the intra- and inter-assay precision, as well as a precision profile, with the latter representing the precision obtained with patient samples. The sample P2 is a single patient serum, samples $\mathrm{K} 1$, $\mathrm{K} 3-\mathrm{K} 8 \mathrm{commercial}$ control sera. The imprecision of $\mathrm{P} 2$ is higher than that of $\mathrm{K} 1$, reflecting a state of affairs often occurring, i.e. that the relative standard deviation $(s \%)$ is higher in native sera than in processed control sera.

The precision control data reflect the excellent precision at the "levels of clinical decision" between hyperand euthyroid patients around $0.2 \mathrm{mU} / 1$ and between eu- and hypothyroid patients around $4 \mathrm{mU} / \mathrm{l}$.

The median concentrations of the 201 sera measured in a correlation study were $1.00 \mathrm{mU} / \mathrm{l}$ for the commercial ILMA and $0.80 \mathrm{mU} / 1$ for the TRIFMA. These data are shown in figure 1 . Both assays classified the patients with confirmed hyperthyroidism and euthyroidism correctly in 193 cases. In five cases, the

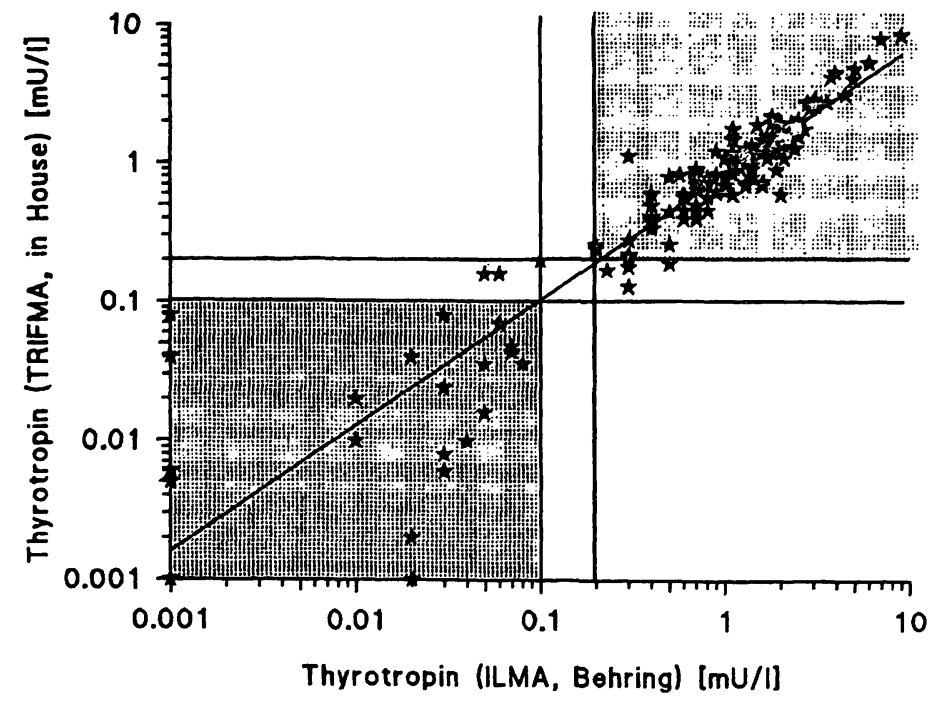

Fig. 1. Comparison of the commercial immunoluminometric assay (Berilux) ( $x$ ) and the time-resolved immunofluorimetric assay $(y)$ as determined on 201 patient sera covering the range $0-10 \mathrm{mU} / \mathrm{l}$. A double logarithmic scale was used to emphasize the values at lower concentrations. Values below the detection limit of each assay were given as $0.001 \mathrm{mU} / 1$. The regression line is $(\log \mathrm{y})$ $=0.91(\log x)-0.08$, the coefficient of correlation $r$ was 0.92 . The hyperthyroid (heavy shading) and euthyroid (light shading) ranges are shown. Discrepant results lie in the areas without shading.

TRIFMA gave results as borderline, the ILMA as euthyroid; in two cases, the TRIFMA classified patients as borderline, the ILMA as hyperthyroid; and in one case, the TRIFMA classified a patient as borderline euthyroid, the ILMA as borderline hyperthyroid.

\section{Discussion}

The continual improvement of immunoassays for proteohormones has led to a more reliable diagnosis in the clinic. The differences between radioimmunoassays and immunometric assays for thyrotropin has been documented elsewhere, as far as performance is concerned. The in-vitro differentiation between hyperand euthyroidism first became possible with the introduction of the immunoradiometric assays for thyrotropin. The reduction of assay times from several days to a couple of hours made emergency confirmation of overt hyperthyroidism or thyrotoxic crisis possible, with the results being back on the ward within two or three hours $(1-3,7)$.

The assay reproducibility at low analyte levels was vastly improved by the reduction of the detection limit and by the robust assay design.

The introduction of non-radioisotopic labelling has not only removed the hazards of radionuclides, but 
has also led to a further improvement in assay lower detection limits and to the shelf-life of components, especially the tracer. In addition, the circle of immunoassay kit users has been increased, as no licensing of laboratories for radioisotopes is needed for the non-radioisotope labelled kits.

It is important not to forget the problems of measuring low analyte concentrations where "matrix effects" play a significant role (11). At worst, the effects may give rise to spuriously elevated results due to non-specific binding of tracer in two-site immunometric assays (7). The causes are many and include immunoglobulins $(12,13)$, anti-mouse IgG (14) and rheumatoid factor (15), to name but three. Vaidya \& Beatty (16) have investigated the sources of interference in assays using creatine kinase-MB as a model system.

From the above studies and observations it is clear why the aim must be to develop assays that are insensitive to such effects of components in the matrix $(11,16)$.

The assay described here appears to fulfil the criterion, at least under the conditions tested, of being matrixindependent. That the assay results are identical, independent of whether the standards are dissolved in assay buffer, foetal calf serum or human serum from a thyrotoxic patient supports the claims of the assays

\section{References}

1. Seth, J., Kellett, H. A., Caldwell, G., Sweeting, V. M., Beckett, G. J., Gow, S. M. \& Toft, A. D. (1984) A sensitive immunoradiometric assay for serum thyroid stimulating hormone: A replacement for the thyrotrophin releasing hormone test? Br. Med. J. Clin. Res. 289, 1334-1336.

2. Soos, M., Taylor, S. J., Gard, T. \& Siddle, K. (1984) A rapid, sensitive two-site immunometric assay for TSH using monoclonal antibodies: Investigation of factors affecting optimisation. J. Immunol. Meth. 73, 237-249.

3. Cobb, W. E., Lamberton, R. P. \& Jackson, I. M. (1984) Use of rapid sensitive immunoradiometric assay for thyrotropin to distinguish normal from hyperthyroid subjects. Clin. Chem. 30, 1558-1560.

4. John, R., Henley, R., Chang, D. \& McGregor, A. M. (1986) Enhanced luminescence immunoassay: Evaluation of a new more sensitive thyrotropin assay. Clin. Chem. 32, 21782183.

5. Jackson, T. M. \& Ekins, R. P. (1986) Theoretical limitations on immunoassay sensitivity. Current practice and practical advantages of fluorescent $\mathrm{Eu}^{+3}$ chelates as non-radioisotopic tracers. J. Immunol. Meth. 87, 13-20.

6. Nicoloff, J. T. \& Spencer, A. A. (1990) The use and misuse of the sensitive thyrotropin assays. J. Clin. Endocrinol. Metab. 71, 553-558.

7. Wood, W. G., Waller, D. \& Hantke, U. (1985) An evaluation of six solid-phase thyrotropin (TSH) kits. J. Clin. Chem. Clin. Biochem. 23, 461-471. as being relatively free from serum matrix effects. The addition of "blocking antibodies" (MAK 33 - anti CK-MM Boehringer-Mannheim) is designed to act against so-called human-anti-mouse-antibodies sometimes present in patients treated for cancer with tagged monoclonal antibodies (12). As the antibody used to coat the solid phase was of murine origin, it was not surprising to find that the non-specific binding of tracer to the solid-phase was reduced, and that no spurious results were obtained from the patient sera, although no screening for anti-mouse antibodies had been made, in contrast to other studies $(14,16)$.

The excellent correlation with the commercial kit in the lower concentration range emphasizes the quality of the assay developed here. The values that lie below those of the commercial kit document the extremely low background of the europium fluorescence in the assay developed.

This short communication shows that it is still possible to develop immunoassays in hospital laboratories with comparable performance to those from commercial kits. This may not be of primary interest in the industrialised countries, but may play a major role in developing countries. The method developed here was made in conjunction with the International Council for Control of Iodine Deficiency Disorders (ICCIDD).

8. Bassett, F., Eastman, C. J., Ma, G., Maberly, G. F. \& Smith, R. C. (1986) Diagnostic values of thyrotrophin concentrations in serum as measured by a sensitive immunoradiometric assay. Clin. Chem. 32, $461-464$.

9. Wood, W. G. (1989) A universal solid-phase immunoassay system based on avidin-biotin reagents. Ärztl. Lab. 35, $29-34$.

10. Wood, W. G. (1992) Luminescence immunoassay - An overview 1990. In: Luminescence: Phenomena, Materials and Devices (Rao, R. P., ed.) Nova Science Publishers, Commack, pp. 363-377.

11. Wood, W. G. (1991) Matrix effects in immunoassays. Scand. J. Clin. Invest. 51, Suppl. 205, 105-112.

12. Howanitz, P. J., Howanitz, J. H., Lamberson, H. V. \& Ennis, K. M. (1982) Incidence and mechanism of spurious increase in serum thyrotropin. Clin. Chem. 28, 427-431.

13. Weber, T. H., Kapyaho, K. I. \& Tanner, P. (1990) Endogenous interference in immunoassays in clinical chemistry. A review. Scand. J. Clin. Invest. 50. Suppl. 201, 77-82.

14. Ferroni, P., Milenic, D. E., Roselli, M., Carrasquillo, J. A., Raubitschek, A., Schlom, J. \& Colcher, D. (1990) Potential for artifacts in monitoring for the detection of tumorassociated antigens (TAG-72 and CEA) in serum from patients undergoing MAb-based diagnostic and therapy protocols. Int. J. Biol. Markers 5, 166-176. 
15. Ziola, B., Halonen, P. \& Enders, G. (1986) Synthesis of measles-virus specific IgM antibodies and IgM-class rheumatoid factor in relation to clinical onset of subacute sclerosing panencephalitis. J. Med. Virol. 18, 51-59.
16. Vaidya, H. C. \& Beatty, B. G. (1992) Eliminating interference from heterophilic antibodies in a two-site immunoassay for creatine kinase $\mathrm{MB}$ by using $\mathrm{F}\left(\mathrm{ab}^{\prime}\right)_{2}$ conjugate and polyclonal mouse IgG. Clin. Chem. 38, 1737-1742.

Prof. W. G. Wood

Institut für Klinische Laboratoriumsdiagnostik

Klinikum der Hansestadt Stralsund

Große Parower Straße 47-53

O-2300 Stralsund

Bundesrepublik Deutschland 


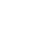

